\title{
Profitability of Backyard Poultry Farming in Sokoto Metropolis, Sokoto State, North-West, Nigeria
}

\author{
M.A. Maikasuwa and M.S.M. Jabo \\ Dept. of Agric. Economics \&Extension, Faculty of Agric. Usmanu Danfodiyo University, Sokoto, Nigeria \\ [Corresponding Author: E-mail: mkzuru2002@yahoo.co.uk]
}

\begin{abstract}
The study was carried out to determine the profitability of backyard poultry production in Sokoto metropolis. Multistage sampling was used to draw 100 samples of backyard poultry farmers used for the study. Data were obtained using structured questionnaire. Data analyses were done using descriptive statistics, farm budgeting and linear regression. Results showed that majority of the backyard poultry farmers were aged between 21-30 years (57.14\%). Most of them were male (62\%) and have acquired tertiary education (82\%). The flock size owned by the majority $(64 \%)$ was between the ranges of 10-50 birds. The major source of investment capital of the enterprise was personal savings (82\%). The results further showed that variable costs were the most important costs accounting for $88.41 \%$ of the total cost and the net farm income per respondent was N48, 745.58 per annum. The linear regression result revealed that cost of chicks $(\mathrm{P}<0.01)$, housing $(\mathrm{P}<0.1)$ and drinkers $(\mathrm{P}<0.1)$ had significant positive contribution while cost of heating $(\mathrm{P}<0.01)$ had significant negative contribution to output generation from the enterprise. Disease outbreak was the most serious problem affecting backyard poultry production in the study area. It is concluded that the enterprise was profitable and it was dominated by male who were mostly married. There was no credit availability to boost the enterprise and farmers in the business were faced with the problem of disease outbreak. These invariably affected the overall performance of the enterprise. It was therefore, recommended that credit institutions be encouraged to make loan available to those people engaged in the enterprise.

Key words: Profitability, Backyard, Poultry, Production
\end{abstract}

\section{INTRODUCTION}

The Importance of poultry production for economic and social development of the people in any nation cannot be over emphasized. Olayemi and Robert (1979) claimed that poultry production in Nigeria as well as other warm climate countries has a high priority rating compared with other types of livestock because poultry has better energy and protein conversion ratio and that net returns on investment are relatively high. Poultry can be established with minimum capital and as a side project (Sani and Tahir, 2000). Goubadia (1996), remarked that poultry industry constitutes an important agricultural enterprise in terms of profitability and quick economic returns in Nigeria. The industry also plays a major role in food production in the livestock sub-sector of the Nigerian economy. This sub-sector produced about $36.5 \%$ of the total protein intake of Nigeria.

Backyard poultry farmers are those poultry farmers that usually raise the birds at the back of their houses. The flock of birds they raised is usually between 20-50 birds. Most of these farmers are low income earners while some are middle income earners. Some of them go into poultry simply for profit making while some go into the production in order to provide additional protein for their family.

Backyard poultry farmers especially in Sokoto metropolis do not keep adequate record of their poultry farming activities. The absence of adequate poultry production record disallows farmers to effectively assess the profitability of their enterprise although Philips (1991) has pointed out that assessment of true profit of any backyard poultry production is difficult to do accurately. This is so because to make an accurate calculation you must take into account not only the money spent or received from sale but also fluctuations in the value of a product. However, Norman, (1985), Olukosi and Erhabo (1988) employ tools like farm budgeting to estimate the profitability of poultry enterprises without necessarily considering any decrease or increase 
in the value of the poultry products. This research is aimed at determining the levels of inputs used and profitability of backyard poultry production in Sokoto metropolis. It is expected that the study shall give an insight into the profitability of the enterprise in the study area.

\section{METHODOLOGY}

The study area: The study was carried out in Sokoto metropolis. Sokoto State is located in the extreme north-western part of Nigeria. It is located between latitudes $4^{\circ}-6^{\circ} \quad 40 \hat{\alpha}$ and longitudes

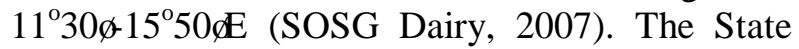
has an estimated population of 3,696,999 (NPC, 2006). The predominant tribes are the Hausa/Fulani who are mostly Muslims. Other tribes found in the state are Zabarmawa, Igbo, Yoruba and Nufawa. Sokoto metropolis covers part of Wamakko, Kware, Sokoto north and Sokoto south.

Sokoto falls within the Sudan Savannah ecological zone.The annual average temperature is $28.3^{\circ} \mathrm{C}$. The climate of the state is largely controlled by two recasting air masses. The moist tropical maritime from the south which blows from the Atlantic Ocean and the tropical continental wind from the north across the Sahara which is dry and dusty that brings the harmattan (SMANR, 2007). The rainy season is from June to October, The mean annual rainfall is $750 \mathrm{~mm}$ and potential evapo-transpiration rate has been reported to be $102 \mathrm{~cm}$. Major livestock grown in the state include cattle, sheep, goats and poultry (Mamman et al., 2000).

Sampling technique and data collection: Multistage sampling technique was used to draw 100 respondents that were used for the study. The first stage involved random selection of 10 poultry producing areas within Sokoto metropolis. The second stage involved purposive selection of 10 backyard poultry farmers from each of the 10 poultry producing areas already selected given a total of 100 respondents. Two sources of data were used; these are primary and secondary sources. The primary data were collected using questionnaire. The secondary information was obtained through consultations of journals, textbooks, newspapers past projects and other publications that are found to be relevant to the research.

Data analysis: Socio-economic characteristics of the respondents such as age, marital status, years of experience and problems faced in backyard poultry farming were analysed using descriptive statistics such as frequency and percentages. Farm budgeting was used to analyse the profitability of the enterprise and the input-output relationship was examined using multiple linear regression. The relative influence of any given explanatory variable on output in the linear regression equation is determined by the magnitude, sign and statistical significance of its regression coefficient.

Specification of the Model: The farm budgeting model was pecified as follows:

NFI = TR - TVC ï TFC

Where: NFI = Net farm income realised $(\$)$

$\mathrm{TR}=$ total revenue $(\mathbb{N})$

TVC $=$ total variable cost $(\#)$

TFC $=$ total fixed cost $(\mathbb{N})$

The linear production function model was specified as follows:

$\mathrm{Y}=\mathrm{a}+\mathrm{b}_{1} \mathrm{x}_{1}+\mathrm{b}_{2} \mathrm{x}_{2}+\mathrm{b}_{3} \mathrm{x}_{3}+\mathrm{b}_{4} \mathrm{x}_{4}+\mathrm{b}_{5} \mathrm{x}_{5}+\mathrm{b}_{6} \mathrm{x}_{6}+\mathrm{b}_{7} \mathrm{x}_{7}+\mathrm{b}_{8} \mathrm{x}_{8}$

$+\mathrm{e}$

$\mathrm{Y}=$ gross revenue $(\mathrm{N})$

$\mathrm{X} 1=$ Cost of housing $(\mathbb{N})$

$\mathrm{X} 2=$ Cost of feeders

$\mathrm{X} 3=$ Cost of drinkers $(\mathrm{N})$

$\mathrm{X} 4=$ Transport cost $(\mathrm{N})$

$\mathrm{X} 5=$ Cost of chicks $(\mathbb{N})$

$\mathrm{X} 6=$ Cost of feeds $(\#)$

$\mathrm{X} 7=$ Cost of heat $(\mathrm{N})$

$\mathrm{X} 8=$ Cost of drugs $(\sharp)$

$\mathrm{e}=$ error term

$\mathrm{b}-\mathrm{b}=$ Regression coefficients

Table1 shows the demographic characteristics of the respondents. Information pertaining to age reveals that majority of the backyard poultry farmers $(57.14 \%)$ were between the age ranges of 21-30years. Only $4.08 \%$ of them were between the age ranges of 41-50years. This shows that backyard poultry farming in Sokoto metropolis is dominated by youth. This is probably because of the less initial capital investment involved and the ability of the enterprise to offer a means of income generation 
and employment to the youth. It could also be because the business is an innovation that is riskladden that the youths are more likely to try it than the old.

Information pertaining to sex shows that $62 \%$ of the respondents were male while $38 \%$ were female. This indicates that female participation in backyard poultry farming is low compared to their male counterparts. This is probably because in many traditions in Nigeria, men are the bread winners of most families. They therefore, have to get engaged in income generating activities to raise money in order to provide sustenance for their families.

Information on marital status reveals that $44 \%$ of the respondents were single while $56 \%$ of the respondents were married. This indicates that majority of the respondents were married and they have to find some income generating activities to provide for the family. Information pertaining to level of education shows that $82 \%$ of the respondents had tertiary education while only $2 \%$ had only Qurônic education.

Table1: Distribution of the Respondents According to Demographic Characteristic of the Respondent.

\begin{tabular}{llll}
\hline Variables & Class & Frequency & \% \\
\hline Age & $10-20$ & 6 & 6.12 \\
& $21-30$ & 56 & 57.14 \\
& $31-40$ & 32 & 32.65 \\
Sex & Ó41 & 4 & 4.08 \\
\multirow{4}{*}{ Marital status } & Male & 62 & 62 \\
\multirow{2}{*}{ Religion } & Female & 38 & 38 \\
& Single & 44 & 44 \\
Educational & Married & 56 & 56 \\
level & Islam & 64 & 64 \\
& Christianity & 36 & 36 \\
& Primary & 2 & 2 \\
& Secondary & 14 & 14 \\
& Tertiary & 82 & 82 \\
& Qurânic & 2 & 2 \\
\hline
\end{tabular}

Source: field survey, 2009.

Table 2 shows distribution of the respondents according to type of poultry they engaged in and years of experience. Information pertaining to the type of poultry shows that $46 \%$ of the respondents were involved in broilers production. This is probably due to the fact that broilers production requires low capital but gives high turnover. Information based on the years of experience reveals that majority of the respondents representing $56.25 \%$ have had $1-5$ years of experience while only $2.08 \%$ have had 11 and above years of experience. The greater the level of experience in poultry farming the more effective will be the management practice and the more shall be the amount of income to be generated.

Table2: Type of enterprise and years of experience in poultry production.

\begin{tabular}{llll}
\hline Variables & Class & Frequency & \% \\
\hline Enterprise & Broilers & 46 & 46 \\
& Layers & 30 & 30 \\
& Both & 24 & 24 \\
Years of & $1-5$ & 54 & 56.25 \\
Experience & $6-10$ & 40 & 41.66 \\
& Ól 1 & 2 & 2.08 \\
\hline
\end{tabular}

Source: field survey, 2009.

Table 3 shows the distribution of the respondents according to the number of birds raised. The result shows that $64 \%$ of the respondents had a flock size of $10-50$ birds while only $8 \%$ of the respondents had a flock size of 101-150 birds. This indicates that backyard poultry business does not allow for large-scale production probably due the limited space available to the producers.

Table 3: Distribution of respondents according to number of birds raised.

\begin{tabular}{lll}
\hline Number of birds raised & Frequency & $\mathbf{\%}$ \\
\hline $10-50$ & 64 & 64 \\
$51-100$ & 28 & 28 \\
$101-150$ & 8 & 8 \\
Ó 51 & 0 & 0 \\
\hline
\end{tabular}

Source: field survey, 2009.

Table 4 shows the distribution of respondents according to the sources of finance for poultry business. The result shows that $82 \%$ of the respondents used money from their personal savings as initial capital while $18 \%$ borrowed from their friends. This reveals that, there is limited availability of funds for backyard poultry 
producers. It is also revealing that banks do not lend money to backyard poultry farmers.

Table 4: Distribution of respondents according to source of finance.

\begin{tabular}{lll}
\hline Source of finance & Frequency & $\mathbf{\%}$ \\
\hline Loan from bank & 0 & 0 \\
Personal saving & 82 & 82 \\
Borrowed from friend & 18 & 18 \\
Money lenders & 0 & 0 \\
\hline
\end{tabular}

Source: field survey, 2009.

Table 5 shows profitability analysis of the enterprise. The table shows that variable costs are the most important costs in backyard poultry production accounting for $88.41 \%$ of the total cost. The total cost of production was $\$ 12538.58$ per annum and the average net farm income generated per respondent from the enterprise was \$48745.58 per annum. This indicates that backyard poultry production in Sokoto metropolis is profitable. The result conforms to Sani and Tahir (2000) who observed that backyard poultry production requires minimum capital investment to make huge profit.

Table 5: Profitability analysis of the backyard poultry enterprise in Sokoto metropolis per annum.

\begin{tabular}{lll}
\hline Variable & $\begin{array}{l}\text { Total } \\
\text { cost }\end{array}$ & Average cost \\
\hline Chicks & 167000 & 16700 \\
Transport & 11900 & 119 \\
Feeds & 729700 & 7297 \\
Heat & 46900 & 469 \\
Drugs & 153000 & 1530 \\
Total variable cost & 1108500 & $11085.00(88.4 \%)$ \\
Feeders & 7778 & 77.78 \\
Drinkers & 7164 & 71.64 \\
House & 130416 & 1304.16 \\
Total fixed cost & 145358 & $1453.58(11.6 \%)$ \\
Total cost & 1253858 & $12538.58(100 \%)$ \\
Gross revenue & 6128400 & 612840 \\
Net farm income & 4874542 & 48745.42 \\
\hline
\end{tabular}

Source: field survey, 2009.

Table 6 shows the result of the production function analysis. The table shows the relationship between the poultry output and amount of inputs used in the production process. Input considered to be influencing poultry production are housing, feeders, drinkers, chicks, transport, feeds, heating, drugs and the rate of their influence was measured by the regression coefficient. The coefficient of chicks was positive and significant (P Ò 0.01) implying that a unit increase in spending on chicks would increase the output by $\$ 1.078$ when all other factors were held constant. The cost of housing and that of drinkers were also significant (P Ò 0.1) implying that increasing expenditure on the inputs would bring about significant increase in revenue realization. The cost of transport, feed, drugs and feeders were not significant which means any increase or decrease in expenditure on these inputs would not bring about any change in revenue realized from the enterprise. Heating (POे.01) on the other hand had a significant negative influence on revenue generation on the enterprise. The $\mathrm{R}^{2}$-value shows that $47.5 \%$ out of $100 \%$ was due to influence of input on the output.

Table 6: Result of linear regression analysis on backyard poultry production.

\begin{tabular}{lllll}
\hline Variable & Coefficient & $\begin{array}{l}\text { t- } \\
\text { value }\end{array}$ & $\begin{array}{l}\mathbf{R}^{2}- \\
\text { value }\end{array}$ & F-value \\
\hline Constant & $61118.511^{* * * *}$ & 4.220 & 0.475 & $10.195^{* * *}$ \\
House & $-12.803^{* *}$ & -1.768 & & \\
Drinkers & $115.875^{*}$ & 1.776 & & \\
Feeders & $21.738_{\mathrm{N} . S}$ & 0.380 & & \\
Chicks & $1.078^{* * *}$ & 4.182 & \\
Transport & $102.563^{\text {N.S }}$ & 1.158 & \\
Feeds & $0.585^{\text {N.S }}$ & 1.089 & \\
Heat & $-76.860^{* * *}$ & -4.726 & \\
Drugs & $5.517^{\text {N.S }}$ & 1.352 & \\
\hline Source: field survey, 2009. & \\
${ }_{* * * *}^{*}=$ significant at $\mathrm{P}<0.01,{ }^{*}=$ significant at $\mathrm{P}<0.1$ and \\
N.S= non significant.
\end{tabular}

Table7 shows the distribution of respondents based on the problems encountered in the production process. The table shows that $40 \%$ of the respondents encounter disease outbreak which was probably due to poor management. Also $10 \%$ of the respondents encountered problems of inadequate finance and this may be due to none availability of loan from the banks and government organization to the farmers. The table also shows that $18 \%$ of the respondents encountered the problem of cannibalism while $6 \%$ of the respondents complained about the need for change of litter. 
Table7: Distribution of respondents according to problems encountered in poultry production.

\begin{tabular}{lcc}
\hline Problems & Frequency & $\mathbf{\%}$ \\
\hline Inadequate finance & 10 & 10 \\
Outbreak of disease & 40 & 40 \\
Shortage of water & 8 & 8 \\
Shortage of feed & 10 & 10 \\
Cannibalism & 18 & 18 \\
Extreme weather & 8 & 8 \\
Change of litters & 6 & 6 \\
\hline
\end{tabular}

Source: field survey, 2009

\section{CONCLUSION AND RECOMMENDATION}

It is concluded that the business of backyard poultry farming in Sokoto metropolis was profitable despite the fact that there was limited credit availability to boost the enterprise and farmers in the business were faced with the problem of disease outbreak. These invariably affected the overall performance of the enterprise. It was therefore, recommended that more peopleparticularly females be encouraged to take part in backyard poultry farming and commercial banks in the state be encouraged to make credit available to those interested in the business. This shall not only help to increase the level of protein supply in the Sokoto metropolis, but shall also open opportunities for job creation and income generation particularly among youths in the State.

\section{REFERENCES}

Goubodia E.E. (1996). An Assessment of the Impact of the Structure Adjustment
Programme (SAP) on Poultry in Nigeria Vol. 14. 272p.

Mamman, A.B., Oyenbanji, J.O. and Peter, S.W. (2000). Nigeria: A purple united, A future assumed - Survey of states. Federal Ministry of Information, Abuja, Millinium edition.

National Population Commission (NPC) (2006). Population of Nigeria by Sex. Sokoto State.

Norman, D.W. (1985). Economic analysis of poultry production and labour utilization in Northern Nigeria, J. Appl. Econ. 4 (26): 18-24

Olayemi. J.A. and Roberts, F.A. (1979). Poultry production in warm Bauchi State. A case study of Bauchi Local Government Area. Nig. J. Animal. Prod. 27: 109-113.

Olukosi, J.O. and Erhabor (1988). Introduction to farm management economics: Principle and Application, Ndahi prss, Sabon Gari, Zaria, Nigeria.

Philips, S. (1991). Management of Poultry business in Sub-Sahara Africa: Zion International Ltd, S/Africa

Sani, R.M. and Tahir, S. (2000). Economic of Poultry production in Bauchi State. A case study of Bauchi Local Government Area. Abubakar Tafawa Balewa University, Bauchi Sate.

SMANR (2007). Annual Report of the Ministry of Agriculture and Natural Resources, Sokoto state pp8-11

Sokoto State Government Dairy (2007). Yearly publication by the Dept. of Home Affairs, Sokoto State, Pp 1-3. 